How to Cite: Mustafin, Ye.S., Omarov, Kh.B.,Borsynbaev, A.S., Havlichek, D., Pudov, A.M., Shuyev, N.V. (2021) Production of electrolytic copper from Zhezkazgan Processing Plant tailings leaching solutions using a hydro-pulse discharge. Bulletin of the University of Karaganda - Chemistry, 104(4), 128-137. https://doi.org/10.31489/2021Ch4/128-137

\author{
Ye.S. Mustafin ${ }^{1}$, Kh.B. Omarov ${ }^{1}$, A.S. Borsynbaev ${ }^{1 *}$, \\ D. Havlichek ${ }^{2}$, A.M. Pudov ${ }^{1}$, N.V. Shuyev ${ }^{1}$ \\ ${ }^{1}$ Karagandy University of the name of academician E.A. Buketov, Karaganda, Kazakhstan; \\ ${ }^{2}$ Charles University, Prague, Czech Republic \\ (*Corresponding author's e-mail: askhat.9@mail.ru)
}

\title{
Production of electrolytic copper from Zhezkazgan Processing Plant tailings leaching solutions using a hydro-impulse discharge
}

\begin{abstract}
In this work, for the first time, studies of the mineralogical composition and chemical semi-quantitative spectral analysis (SQSA) of the Zhezkazgan processing plant tailings before and after leaching were carried out. It was found that copper is present in the tailings in the form of the chalcosine and bornite minerals. After leaching with the use of ammonium bifluoride and a hydro-pulse discharge, chalcosine and boronite are destroyed, and copper passes into a solution containing phosphoric acid. As a result of multiple placing of tailings into the solution, the copper content in it is brought to a concentration at which copper deposition on a stainless steel plate is possible. The identification of copper was implemented on a LAES-Matrix grain spectrometer. A visual comparative analysis of the changes in the structure of the treated ore waste was carried out using a TESCAN MIRA scanning electron microscope. Metallic copper was obtained from solution by electrochemical reactions in an experimental laboratory setup as a result. The technology was developed on an experimental laboratory setup for the extraction of metallic copper and brought the choice of the solution medium and electrochemical processes to the stage of obtaining the target metal with a purity of $99.99 \%$.
\end{abstract}

Keywords: hydro-impulse discharge, reactor, pulp, ammonium hydrofluoride, tailings samples, mineralogical composition, copper, electrolysis.

\section{Introduction}

The currently used beneficiation processes do not provide full extraction of useful components from minerals due to the constructive parameters of the working equipment and apparatuses, so they cannot be taken when developing off-balance sheet reserves of deposits [1].

Modernization of enrichment processes is carried out by involving hydrometallurgical and chemical processing operations, which increase the efficiency of enrichment through the use of a new type of energy, for example, reagent leaching technologies for metals.

One of the rapidly developing trends in the leaching of non-ferrous metals today can be considered the use of electro-hydro-impulse discharge (HID) technology. HID is characterized by a high coefficient of efficiencyand universal capabilities of ultra-high pressures in combination with electromagnetic properties. The content of valuable components both in ores and concentrates extracted from dump tailings is usually low. That is why, the complete extraction of valuable metals from ore is impossible without the use of modern enrichment methods, such as the method of electro-hydro-impulse action $[2,3]$.

Currently, the use of ammonium salts is gaining new relevance due to their high productivity in the leaching of copper from hydrometallurgical production waste. They have the properties of breaking the intermolecular bonds of copper compounds and silicon compounds, thereby releasing the target product from the minerals. The study showed that when exposed to $\mathrm{NH}^{4+}$ ions at a concentration of $1.29 \mathrm{~mol} / \mathrm{l}$, as well as the impact of physical parameters such as partial pressure, time, mixing intensity, temperature, particle size, on the minerals chalcopyrite and siderite, the extractivity is $95 \%$ of the ore mass. Then the kinetics of $\mathrm{Cu}$ leaching with a total content of $8.8 \%$ of the ore mass indicates the feasibility of using ammonia derivatives for copper leaching [4]. The ability to form an unstable $\mathrm{NH}_{3} \mathrm{c} \mathrm{Cu}{ }^{+2}$ complex makes it possible to extract copper not only from the enriched ore, but also from their depleted products of the hydrometallurgical process, which together makes it possible to completely extract copper and other metals of the transition group of the periodic system of elements from ores without residues [5, 6]. For example, the authors [7] carried out work on the hydrofluoride opening of mines of scheelite, wolframite, ilmenite, sphene, baddeleyite, datolite, crystalline quartz and gold-containing technogenic waste. It is established that during fluorination, ammonium fluoro or oxofluorometallates are formed, which provide the solubility of the products and the possibility 
of separating the mixtures by sublimation. It is shown that the opening of mineral raw materials with ammonium hydrodifluoride proceeds at low temperatures and allows for the extraction of all valuable components in the form of final oxides or intermediate simple and complex fluorides according to similar schemes.

The copper production industry in Kazakhstan has a huge potential for development with the introduction of new innovative and environmentally friendly methods of integrated ore processing, covering previously unused waste-tailings stored in the form of dumps. In this work, the "electro-hydro-impulse effect" was used, which allows achieving a high-quality yield of metals from the tailings of the Zhezkazgan processing plant (ZPP) at relatively low energy costs.

The aim of the study is to study the changes in the mineralogical composition of the tails of the Zhezkazgan processing plant after leaching by hydro-impulse discharge and deposition of copper on stainless steel by electrolysis from a fluid.

\section{Experimental}

A laboratory setup has been developed and installed for experimental work on the processing of studied samples of mining waste by electro-hydro-impulse (HID) exposure. This makes it possible to conduct experiments in a wide range of changes in the characteristics of the electric discharge.

Extraction of metals was carried out in a 11 cell, where $250 \mathrm{~g}$ of tailings of ZPP 1, ZPP 2, ZPP 3 were filled in, then $500 \mathrm{~g}$ of water was poured and $4 \mathrm{~g}$ of $\mathrm{NH}_{4} \mathrm{HF}_{2}$ were added [8].

Then it was treated with an electro-hydro-impulse discharge (HID) in the cell for 15 minutes, after that $15 \mathrm{ml}$ of $\mathrm{H}_{3} \mathrm{PO}_{4}$ was added to $\mathrm{pH} 1-2$, and GIR was treated in the cell for another 15 minutes.

Next, $100 \mathrm{ml}$ of water was added, after filtration, the total solution was checked with a $\mathrm{pH}$ meter $(\mathrm{pH}$ meter / Etan ionomer) and brought to $\mathrm{pH}=1-2 \mathrm{H}_{2} \mathrm{SO}_{4}$, then sedimentation on iron plates was carried out and the purity of the resulting copper was determined. The purity of copper deposition on the plate was implemented on a Laser atomic emission spectrometer "SPEKS LAES Matrix Continuum".

The assembled installation is composed of the main blocks and nodes. The remote control for starting a high-voltage generator with current and voltage output sensors is made with a controlled transformer for $220 \mathrm{~V}$. To obtain high-voltage electrical pulses, a pulse voltage generator was assembled. The generator unit consists of a high-voltage transformer, a high-voltage AC rectifier, a spark gap with a cell (reactor) and a circuit protection circuit for the generator housing, electricity metering devices (Fig. 1).

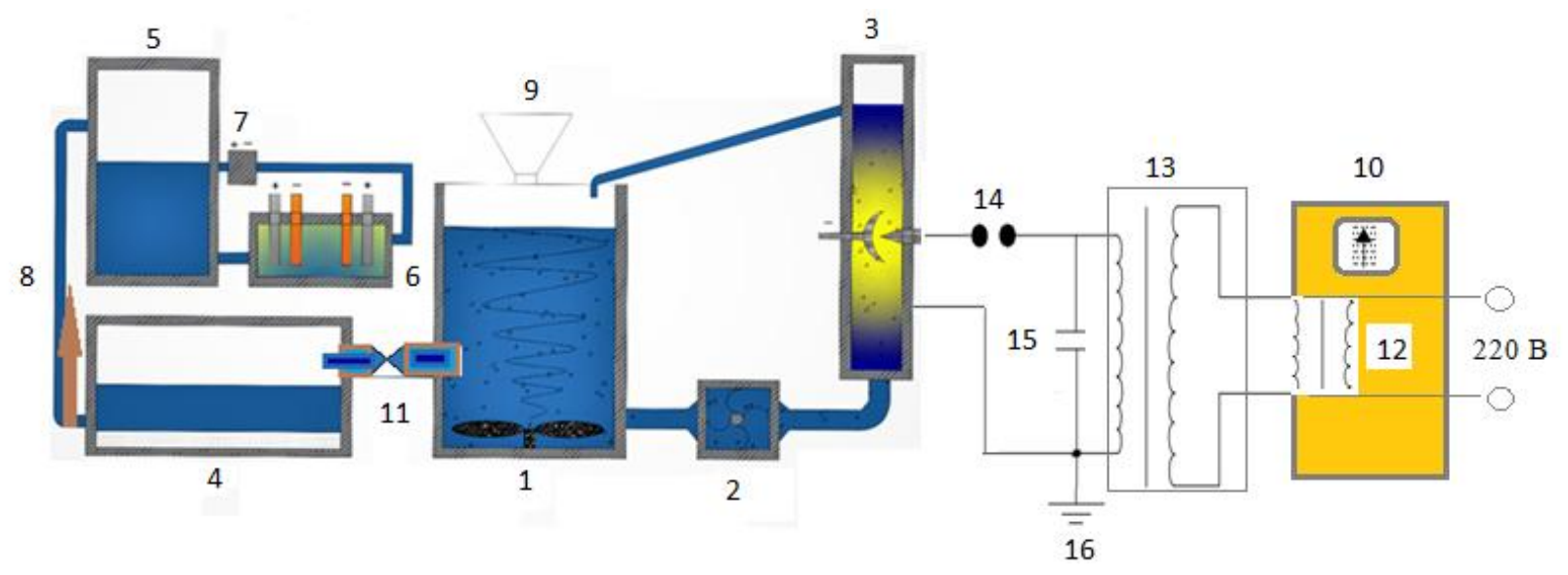

Figure 1. Diagram of a laboratory setup for extracting copper from the tailings of the ZPP 1, 2, 3

Description of a laboratory setup:

1. Stirring machine $\mathrm{v}=20 \mathrm{l}$;

2. Pump feeding the pulp;

3. Pulp discharge reactor;

4. Decantator (sediment separation) with filtration;

5. Collector of the working fluid of the electrolyte $v=10 \mathrm{l}$;

6. Electrolyzer $\mathrm{v}=5 \mathrm{l}$;

7. Circulation pump for electrolyte;

8. Post-decantation fluid supply pump with non-return valve; 
9. Tailings loading hopper with water and reagents supply;

10. Hydraulic pulse control panel (HIR);

11. Switch valve for the solution supply to the reactor and decantator;

12. Low-voltage controlled transformer for $220 \mathrm{~V}$;

13. High voltage transformer up to $60 \mathrm{kV} / \mathrm{A}$;

14. Discharge switch;

15. $0.4 \mathrm{mF}$ capacitor;

16. Grounding.

An I-160 MI laboratory ionomer was used to measure the $\mathrm{pH}$ of the medium. A microwave plasma atomic emission spectrometer (MP-AES) duplicated on an AA-140 atomic absorption spectrometer was applied for the quantitative determination of metals. The mineralogical composition of the tailings samples was determined using a Micromed POLAR 2 polarizing microscope. A visual comparative analysis of the changes in the structure of the treated ore waste was carried out using a TESCAN MIRA scanning electron microscope.

\section{Results and Discussion}

It is necessary to know the mineral composition of the samples, the size of mineral grains and the nature of their adhesion when choosing a method for processing ores [9]. This allows to determine the required fineness of grinding and facilitate the choice of methods for processing ore or waste. Table 1 shows the passport data of the imported samples of tailings ZPP-1, 2; ZPP-3.

Table 1

Passport data of "Kazakhmys" LLP tailings samples

\begin{tabular}{|c|c|c|c|c|c|c|c|c|c|}
\hline Name of PP & Tailings & $\mathrm{Cu}$ & $\mathrm{Fe}$ & $\mathrm{Zn}$ & $\mathrm{Pb}$ & $\mathrm{SiO}$ & $\mathrm{Al}_{2} \mathrm{O}_{3}$ & $\mathrm{~S}$ & $\mathrm{CaO}$ \\
\hline ZPP 1, 2 & Current & 0.127 & 2.2 & 0.02 & 0.01 & 63.82 & 11.27 & 0.13 & 6.47 \\
\hline ZPP 1, 2 & Stale & 0.187 & 1.8 & 0.03 & 0.02 & 62.85 & 10.46 & 0.16 & 7.17 \\
\hline ZPP 3 & Stale & 0.176 & 2.3 & 0.04 & 0.02 & 64.68 & 11.88 & 0.16 & 4.76 \\
\hline
\end{tabular}

The mineralogical composition of the obtained tailings samples was studied; the results before and after the HID treatment are represented in Tables $2-4$.

Table 2

Copper content before and after HID treatment

\begin{tabular}{|c|c|c|c|c|c|c|}
\hline \multirow{3}{*}{ Mineral } & \multicolumn{6}{|c|}{ Sample name } \\
\hline & \multicolumn{2}{|c|}{$\begin{array}{c}\text { Stale tailings } \\
\text { ZPP № 1,2 } \\
\end{array}$} & \multicolumn{2}{|c|}{$\begin{array}{l}\text { Current tailings } \\
\text { ZPP № 1, } 2\end{array}$} & \multicolumn{2}{|c|}{$\begin{array}{l}\text { Stale tailings } \\
\text { ZPP № } 3\end{array}$} \\
\hline & $\begin{array}{c}\text { before } \\
\text { leaching }\end{array}$ & $\begin{array}{l}\text { after leach- } \\
\text { ing }\end{array}$ & $\begin{array}{l}\text { before } \\
\text { leaching }\end{array}$ & $\begin{array}{c}\text { after } \\
\text { leaching }\end{array}$ & $\begin{array}{l}\text { before } \\
\text { leaching }\end{array}$ & $\begin{array}{c}\text { after } \\
\text { leaching }\end{array}$ \\
\hline$[\mathrm{Cu}]$, total in \% & 0.213 & 0.024 & 0.13 & 0.012 & 0.176 & 0.014 \\
\hline$\Sigma \mathrm{Cu}$ oxidized phase, $\%$ & $\leq 0.02$ & $<0.01$ & $\leq 0.02$ & $<0.01$ & 0.026 & $<0.01$ \\
\hline $\mathrm{Cu}$, free oxidized $\%$ & $\leq 0.02$ & $<0.01$ & $\leq 0.02$ & $<0.01$ & 0.026 & $<0.01$ \\
\hline $\begin{array}{l}\Sigma \mathrm{Cu} \text { of Malachite+ Azurite } \\
+\mathrm{atacamite}^{2} \\
\mathrm{Cu}_{2} \mathrm{CO}_{3}(\mathrm{OH})_{2}+2 \mathrm{Cu}\left[\mathrm{CO}_{3}\right] \\
\times \mathrm{Cu}[\mathrm{OH}]_{2}+\mathrm{Cu}_{2} \mathrm{Cl}(\mathrm{OH})_{3} \\
\end{array}$ & $\leq 0.02$ & $<0.01$ & $\leq 0.02$ & $<0.01$ & 0.026 & $<0.01$ \\
\hline $\mathrm{Cu}$, chalcosine $\%\left(\mathrm{Cu}_{2} \mathrm{~S}\right)$ & 0.09 & 0.004 & 0.04 & 0.01 & 0.056 & 0.01 \\
\hline $\mathrm{Cu}$, bornite $\%\left(\mathrm{Cu}_{5} \mathrm{FeS}_{4}\right)$ & 0.063 & 0.02 & 0.03 & 0.002 & 0.042 & 0.004 \\
\hline
\end{tabular}

As can be seen from Table 2, copper is contained in the samples in the form of chalcosine and bornite minerals. The highest copper content is found in the sample "Stale ZPP No. 1, 2". After the HID treatment, copper remains only in the form of the chalcosine and bornite minerals in small quantities, and from the remaining minerals it passes into solution. 
Lead content before and after HID treatment

\begin{tabular}{|l|c|c|c|c|c|c|}
\hline \multirow{2}{*}{ Mineral } & \multicolumn{4}{|c|}{ Sample names } \\
\cline { 2 - 7 } & \multicolumn{2}{|c|}{ Stale tailings ZPP № 1, 2 } & \multicolumn{2}{c|}{ Current tailingsZPP № 1,2 } & \multicolumn{2}{c|}{ Stale tailings ZPP № 3 } \\
\cline { 2 - 7 } & $\begin{array}{c}\text { before } \\
\text { leaching }\end{array}$ & $\begin{array}{c}\text { after } \\
\text { leaching }\end{array}$ & $\begin{array}{c}\text { before } \\
\text { leaching }\end{array}$ & $\begin{array}{c}\text { after } \\
\text { leaching }\end{array}$ & $\begin{array}{c}\text { before } \\
\text { leaching }\end{array}$ & after leaching \\
\hline$[\mathrm{Pb}]$, total in \% & 0.025 & 0.003 & 0.014 & 0.002 & 0.025 & 0.002 \\
\hline Galenite $(\mathrm{PbS}), \%$ & 0.011 & 0.001 & 0,008 & 0.001 & 0.012 & 0.001 \\
\hline Cerussite $(\mathrm{PbCO}), \%$ & 0.005 & 0.0 & $<0.002$ & 0.0 & 0.007 & 0.0 \\
\hline $\begin{array}{l}\text { Lead (II) oxide (litharge, } \\
\text { PbO), \% }\end{array}$ & 0.004 & 0.001 & $<0.002$ & 0.001 & 0.004 & 0.001 \\
\hline $\begin{array}{l}\text { Pyromorphite } \\
\left(\mathrm{Pb}_{5}\left(\mathrm{PO}_{4}\right)_{3} \mathrm{Cl}\right)\end{array}$ & 0.003 & 0.001 & 0.0 & 0.0 & 0.002 & 0.0 \\
\hline
\end{tabular}

From Table 3 it can be noticed that lead is mainly contained in the samples in the form of the minerals of galena, cerussite and litharge. In the HID processing field, lead remains in the samples in the form of the minerals of galena and litharge in small quantities.

Table 4

Zinc content before and after HID treatment

\begin{tabular}{|c|c|c|c|c|c|c|}
\hline \multirow{3}{*}{ Mineral } & \multicolumn{6}{|c|}{ Sample names } \\
\hline & \multicolumn{2}{|c|}{ Stale tailings ZPP № 1,2} & \multicolumn{2}{|c|}{ Current tailings ZPP № 1,2} & \multicolumn{2}{|c|}{ Stale tailings ZPP № 3} \\
\hline & $\begin{array}{c}\text { before } \\
\text { leaching }\end{array}$ & $\begin{array}{c}\text { after } \\
\text { leaching }\end{array}$ & $\begin{array}{c}\text { before } \\
\text { leaching }\end{array}$ & $\begin{array}{c}\text { after } \\
\text { leaching }\end{array}$ & $\begin{array}{l}\text { before } \\
\text { leaching }\end{array}$ & $\begin{array}{c}\text { after } \\
\text { leaching }\end{array}$ \\
\hline Zn total, \% & 0.018 & 0.0021 & 0.014 & 0.0027 & 0.019 & 0.0021 \\
\hline Carbonated $\mathrm{Zn}, \%$ & 0.003 & 0.0 & 0.001 & 0.0 & 0.004 & 0.0 \\
\hline $\begin{array}{l}\mathrm{Zn} \text { associated with iron } \\
\text { and manganese oxides, \% }\end{array}$ & 0.007 & 0.001 & 0.002 & 0.001 & 0.007 & 0.001 \\
\hline Zn sphalerite $(\mathrm{ZnS}), \%$ & 0.008 & 0.0011 & 0.01 & 0.001 & 0.004 & 0.001 \\
\hline $\begin{array}{l}\mathrm{Zn} \text { related to } \\
\text { aluminosilicates ,\% }\end{array}$ & 0.003 & 0.0 & 0.001 & 0.0007 & 0.003 & 0.0001 \\
\hline
\end{tabular}

As can be seen from Table 4, zinc is mainly contained in the mineral sphalerite in the samples of stale ZPP 1, 2 and ZPP 1, 2, 3 in minerals associated with iron and manganese oxides. After processing HID, zinc in small quantities remains in the samples of ZPP 1, 2, 3 mainly in the minerals sphalerite and minerals associated with iron and manganese oxides.

A semi-quantitative spectral analysis was performed applyng a LAES-Matrix laser spectrometer to determine the valuable chemical elements in the tailings. The obtained data are illustrated in Table 5.

T a b l e 5

Chemical semi-quantitative spectral analysis (SQSA) before and after treatment

\begin{tabular}{|c|c|c|c|c|c|c|c|}
\hline \multirow{2}{*}{ № } & \multirow{2}{*}{ Metals, \% } & \multicolumn{6}{|c|}{ Sample names } \\
\cline { 3 - 8 } & & \multicolumn{2}{|c|}{ Stale tailings ZPP № 1, 2 } & \multicolumn{2}{c|}{ Current tailings ZPP № 1, 2 } & \multicolumn{2}{c|}{ Stale tailings ZPP № 3 } \\
\cline { 3 - 8 } & & before leaching & after leaching & before leaching & after leaching & before leaching & after leaching \\
\hline 1 & $\mathrm{Ag}$ & 0.0004 & 0.0001 & 0.0001 & 0.0001 & 0.0004 & 0.0001 \\
\hline 2 & $\mathrm{Ba}$ & 0.092 & 0.066 & 0.081 & 0.071 & 0.074 & 0.053 \\
\hline 3 & $\mathrm{Co}$ & 1.2 & 1.1 & 1.3 & 0.6 & 1.3 & 1.0 \\
\hline 4 & $\mathrm{Cu}$ & 0.213 & 0.023 & 0.117 & 0.012 & 0.179 & 0.014 \\
\hline 5 & $\mathrm{Ni}$ & 0.25 & 0.23 & 0.26 & 0.24 & 0.25 & 0.22 \\
\hline 6 & $\mathrm{~Pb}$ & 0.024 & 0.030 & 0.013 & 0.019 & 0.022 & 0.022 \\
\hline 7 & $\mathrm{Sc}$ & 0.8 & 0.009 & 1.0 & 0.008 & 0.9 & 0.010 \\
\hline 8 & $\mathrm{Fe}$ & 0.180 & 2.79 & 0.240 & 1.51 & 0.210 & 2.53 \\
\hline 9 & $\mathrm{Zn}$ & 0.022 & 0.0021 & 0.013 & 0.0027 & 0.035 & 0.0021 \\
\hline
\end{tabular}


It is clearly seen from Table 5 that there are other chemical elements besides copper. These are elements such as zinc, lead, silver and some others, and they are of interest for the development of technologies for their extraction. As can be seen from the data of quantitative analysis in Table 6, the metals in the working solution first go into solution, and then precipitate in the form of phosphates, and also partially form complexes with fluorides.

T a b l e 6

Chemical analysis of sediment after decanting and deposition of other metals

\begin{tabular}{|c|c|c|c|c|c|c|c|c|c|c|}
\hline № & Sample & $\begin{array}{c}\mathrm{Ag} \\
\%\end{array}$ & $\begin{array}{c}\mathrm{Ba} \\
\%\end{array}$ & $\begin{array}{c}\mathrm{Co} \\
\%\end{array}$ & $\begin{array}{c}\mathrm{Cu} \\
\%\end{array}$ & $\begin{array}{c}\mathrm{Ni} \\
\%\end{array}$ & $\begin{array}{c}\mathrm{Pb} \\
\%\end{array}$ & $\begin{array}{c}\mathrm{Sc} \\
\%\end{array}$ & $\begin{array}{c}\mathrm{Fe} \\
\%\end{array}$ & $\begin{array}{c}\mathrm{Zn} \\
\%\end{array}$ \\
\hline 1 & ZPP 1, 2 Stale & 0.0004 & 0.092 & 0.9 & 0.013 & 0.25 & 0.024 & 0.8 & 0.18 & 0.02 \\
\hline 2 & ZPP 1, 2 Current & 0.0001 & 0.08 & 0.12 & 0.02 & 0.26 & 0.013 & 1.0 & 0.240 & 0.013 \\
\hline 3 & ZPP 3 Stale & 0.0004 & 0.074 & 0.5 & 0.014 & 0.25 & 0.022 & 0.9 & 0.210 & 0.035 \\
\hline
\end{tabular}

Table 6 shows that copper remained in solution.

Figure 2 demonstrates the percentage of copper in the fluid to its content in the tailings, after running the pulp through a laboratory unit with HID treatment for 30 minutes in the presence of phosphoric acid.

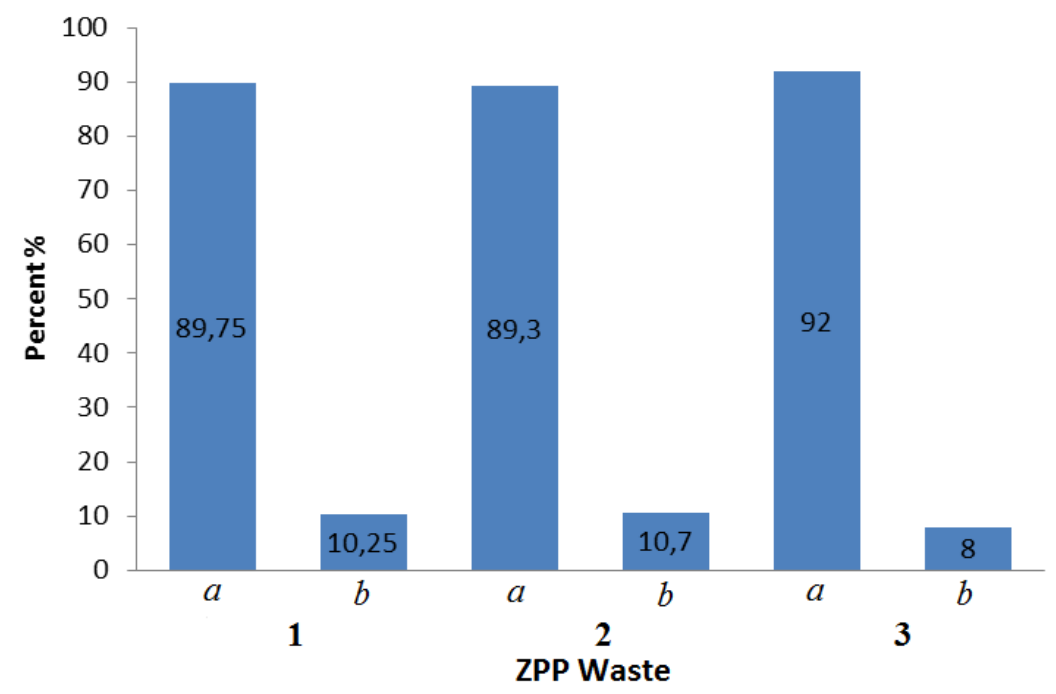

1 - ZPP 1, 2 Stale; 2 - ZPP 1, 2 Current; 3 - ZPP 3 Stale

Figure 2. Diagram of copper content in tailings before $(a)$ and after $(b)$ HID treatment

The average copper content for all fractions was calculated using the formula:

$$
\mathrm{A}=\left(x_{1}+x_{2}+\ldots x_{\mathrm{n}}\right) / n=\sum x_{1} / n=0.114+0.167+0.162 / 3=0.148 .
$$

Heap and underground leaching are widely used to extract copper from poor and off-balance ores or tailings. The main solvent for heap leaching is solutions of iron sulfuric oxide, which are obtained by irrigation of piles with water as a result of pyrite oxidation. Irrigation is carried out consistently with water and solution, followed by cementation of copper with iron scrap. In the case of using a leaching technology, the copper yield was $63.2 \%$ (current ZPP 1,2), $63.6 \%$ (stale ZPP 1,2), $64.2 \%$ (stale ZPP 3).

During the use of a hydro-impulse discharge, the copper yield was $89.75 \% ; 89.3 \% ; 92.0 \%$, respectively.

The first 3 digits are reduced by 63 , and the second by 89.3 for the convenience of calculations, then:

$$
\begin{gathered}
S_{1}{ }^{2}=1 / 3\left[0.45^{2}+2,7^{2}-(0.45+2.7)^{2} / 3\right]=1 / 3[7.21-3.3]=1.3 ; \\
S_{2}{ }^{2}=1 / 5\left[0.2^{2}+0.6^{2}+1.2^{2}-(0.2+0.6+1.2)^{2} / 3\right]=1 / 5[1.84-1.33]=0.10 ; \\
S_{1}{ }^{2} / S_{2}{ }^{2}=13 .
\end{gathered}
$$

The number of freedom degrees were $f_{1}=5, f_{2}=3$. Improvement can only reduce the variance, so we apply a one-sided significance criterion. According to the table of quantiles of the Fisher distribution, we find $F_{0.95(5,3)}=9.0$. We see that $S_{1}{ }^{2} / S_{2}{ }^{2}=13$. Therefore, the observational data allow us to reject the null hypothesis and consider the improvement effective. Thus, the variance of dispersion is significant. 
On the plates, after sedimentation and washing from the solution residues, the copper content was analyzed for its purity from contamination on a laser atomic emission spectrometer "SPEKS LAES Matrix Continuum". The above spectrum clearly shows the analytical lines of copper, which are characterized by high intensity and low content of impurities. The sedimentation of copper on iron plates and the analysis carried out on a laser spectrometer is illustrated in Figure 3, the laser operation zone in the form of burnt circles is clearly visible.
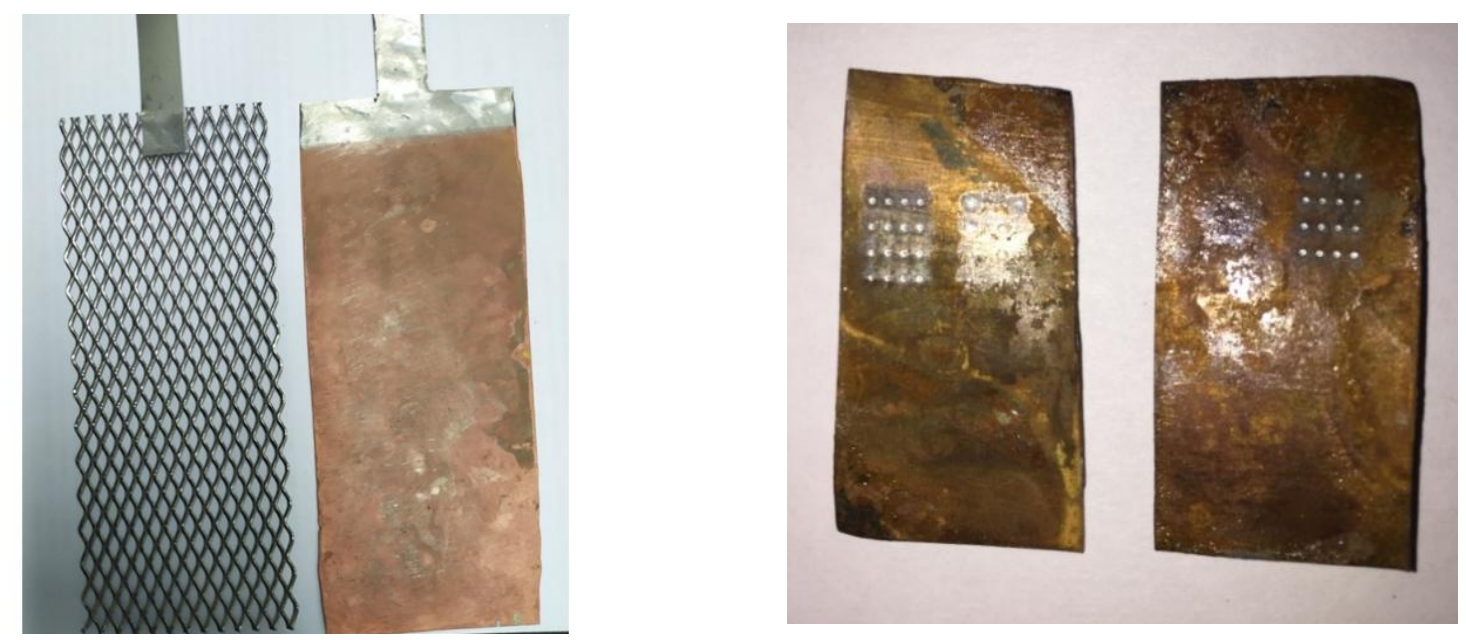

Figure 3. Copper sedimentation on iron plates and laser analysis

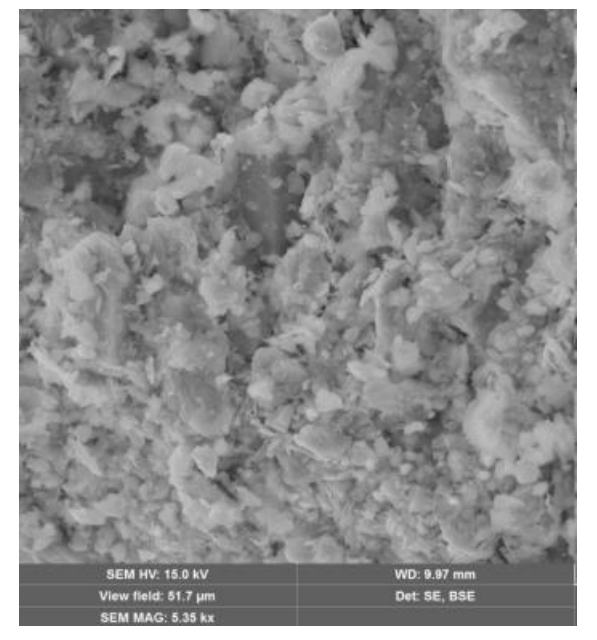

$a$

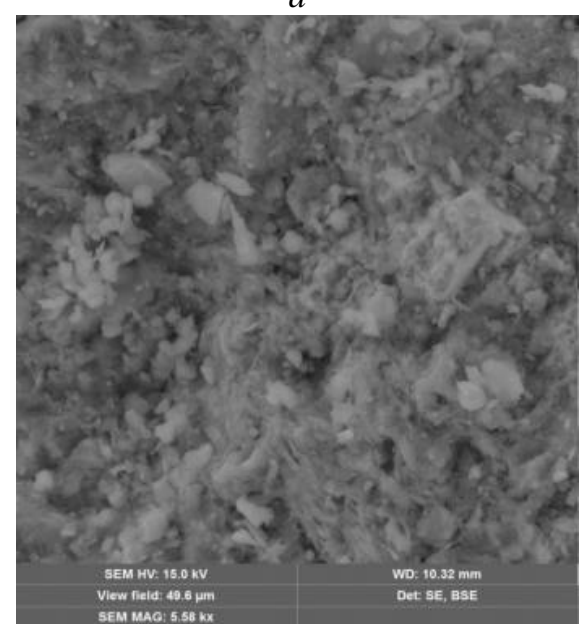

$c$

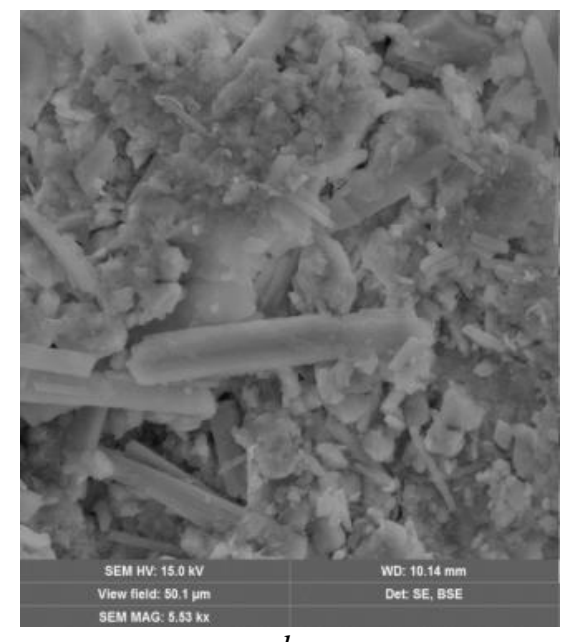

$b$

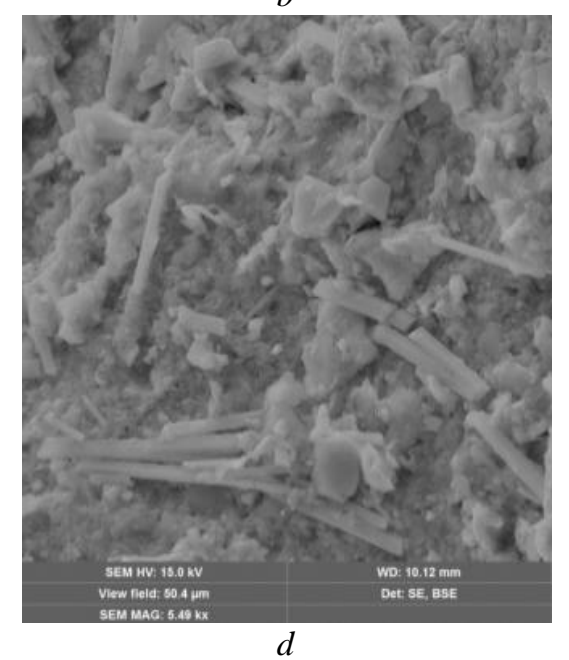




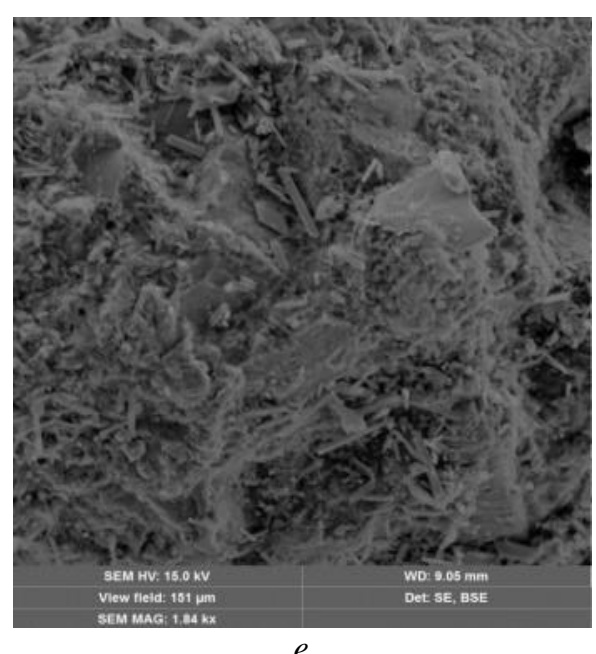

$e$

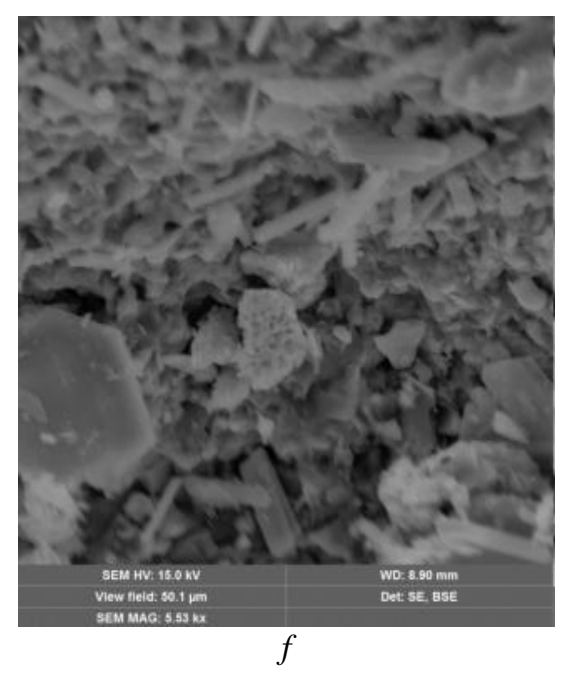

$f$

$a-1,2$ Current tails before HID treatment; $b-$ ZPP 1, 2 tails after HID treatment; $c$ - ZPP 1, 2 stale tails before HID treatment; $d-$ ZPP 1, 2 Stale tails after HID treatment; $e-$ ZPP 3 before HID treatment; $f$ - ZPP 3 after HID treatment

Figure 4. Micrograph of ore waste samples (before and after processing)

To check the sediment remaining after the HID, images of the tailings samples were taken before and after processing (Fig. 4) on the TESCAN MIRA-scanning electron microscope (SEM).

The photos taken with a scanning microscope clearly show the difference between the tail samples before and after the HID treatment: 1) all small particles of clay crumble and dissolve; 2) transparent quartz crystals are clearly visible; 3 ) all mineral and fibrous formations disappear, there is no adhesion of particles to each other.

All this shows that as a result of treatment with HID and 4 grams of ammonium bifluoride $\mathrm{NH}_{4} \mathrm{HF}_{2}$, mainly larger quartz crystals remain, and other types of minerals dissolve with them. After the deposition of other metals and their conversion to insoluble phosphates, the HID laboratory facility worked out the modes of extracting copper from the tailings and subsequent deposition on a stainless steel cathode with a high purity of $99.99 \%$.

\section{Preliminary calculation of energy consumption}

When processing 150 thousand tons of tailings per year, the costs will be:

The cost of equipment is $99,850,000$ tenge.

Materials (provided that the working solution with ammonium bifluoride and sulfuric acid circulates during the daily operation of the installation until it is saturated with copper to approximately $35-38 \mathrm{~kg} / \mathrm{m}^{3}$ ).

$$
150,000 * 34,248 \text { tenge }=5,137,200,000 \text { tenge. }
$$

When organizing the regeneration of ammonium bifluoride and sulfuric acid, i.e. the return to the leaching process of about $70 \%$, the annual cost of materials will be:

Resource costs:

$$
5,137,200,000 \text { tenge } * 0.3=1,541,160,000 \text { tenge. }
$$

- electricity: $150,000 \mathrm{t} * 10,260$ tenge / $\mathrm{t}=1,539,000,000$ tenge;

- water (if the unit is loaded three times for 10 tons of tailings, the loss of water at each discharge will be about 20 liters, that is, the daily additional volume of water will be 24 cubic meters):

365 days $* 24$ cubic meters $* 150=1,314,000$ tenge;

- salary: 3 people $* 180,000$ tenge $* 12=6480000$ tenge.

\section{Conclusions}

The following results were obtained for the first time: the mineralogical composition of the selected tailings samples, which are gray sand with clay inclusions, was determined. In these samples, copper residues are mainly found in the form of the minerals chalcosine and bornite. Then leaching was carried out using ammonium bifluoride hydro-pulse discharge.

A complete chemical analysis of the HID treated samples was carried out on the 4210 MP-AES atomic emission spectrometer, which showed that the metals had passed into solution. Next, the solution was treated 
by acidification of the medium with phosphoric acid to $\mathrm{pH}=1-2$ to transfer other metals to the precipitate. In this solution, HID was repeatedly produced to increase its copper content to a concentration of $0.25 \mathrm{~mol} / \mathrm{l}$.

Electrochemical methods were used to obtain copper deposited on the matrix, where the anode is an oxidized ruthenium-titanium anode (ORTA) mesh, insoluble $3 \times 5 \times 15 \mathrm{~cm}$, and the cathode of non-rusting steel plates is $3 \times 5 \times 15 \mathrm{~cm}$. The purity of the obtained copper on the substrate was determined using an LAESMatrix spectrometer. It was shown that the purity of the obtained copper is $99.99 \%$. An experimental laboratory setup was made, on which the modes of copper extraction on stainless steel plates were worked out.

Then, the images of the tailings samples before and after processing were taken with a TESCAN MIRA scanning electron microscope (SEM) to check the sediment remaining after the HID. It was shown, that all small particles of clay crumble and dissolve; transparent quartz crystals are clearly visible; all mineral and fibrous formations disappear, there is no adhesion of particles to each other.

\title{
References
}

1 Снуриков А.П. Комплексное использование сырья в цветной металлургии: учеб. пос. / А.П. Снуриков. — М.: Металлургия, 2006. - $16 \mathrm{c}$.

2 Goryachev A.A. A study of the Feasibility of Using Ammonium Sulfate in Copper-Nickel Ore Processing / E.V. Chernousenko, S.S. Potapov, N.S. Tsvetov, D.V. Makarov // Metals. - - 2021. - - Vol. 11. - P. 422. https://doi.org/10.3390/met11030422

3 Юткин Л.А. Электрогидравлический эффект и его применение в промышленности: учеб. пос. / Л.А. Юткин. — Л.: Машиностроение, 1986. - $253 \mathrm{c}$.

4 Baba A.A. Characterization and kinetic study on ammonia leaching of complex copper ore / A.A. Baba, M.K. Ghosh, S.R. Pradhan, D.S. Rao, A. Baral, F.A. Adekola // Transactions of Nonferrous Metals Society of China. — 2014. — Vol. 24. P. 1587-1595. https://doi.org/10.1016/S1003-6326(14)63229-5

5 Sinclair L. In situ leaching of copper: Challenges and future prospects / L. Sinclair, J. Thompson // Hydrometallurgy. 2015. — Vol. 157. — P. 306- 324. https://doi.org/10.1016/j.hydromet.2015.08.022

6 Ochromowicz K., Jeziorek M., Wejman K. Copper (II) extraction from ammonia leach solution / K. Ochromowicz, M. Jeziorek, K. Wejman // Physicochem. Probl. Miner. Process. - 2014. — Vol. 50. - P.327-335. https://doi.org/10.5277/ppmp140127

7 Медков М.А. Гидрофторидаммония - перспективный реагент для комплексной переработки минерального сырья / М.А. Медков, Г.Ф. Крысенко, Д.Г. Эпов // Вестн. ДВО РАН. — 2011. — № 5. — С. 60-65.

8 Раков Э.Г. Фториды аммония: учеб. пос. / Э.Г. Раков. - М.: ВИНИТИ, 1988. — 154 с.

9 Минералы: справ. / под ред. Ф.В. Чухрова. - М.: Наука, 1974. — 514 с.

\author{
Е.С. Мустафин, Х.Б. Омаров, А.С. Борсынбаев, \\ Д. Хавличек, А.М. Пудов, Н.В. Шуев
}

\section{Жезқазған байыту фабрикасы қалдықтарына гидроимпульсті разрядты қолдана отырып, ерітінділерінен электролиттік мысты алу}

\begin{abstract}
Мақалада алғаш рет Жезқазған байыту фабрикасының қалдықтарының, өңдеуге дейінгі және өңдеуден кейінгі минералогиялық құрамына және химиялық жартылай сандық спектрлік талдау (PSA) зерттеулері жүргізілген. Мыс қалдықтарында халькозин және борнит минералдары түрінде болатыны анықталды. Аммоний бифторидін және гидроимпульсті разрядты қолданғанда, бөлуден кейін халькозин және борнит ыдырайды, ал мыс құрамында фосфор қышқылы бар ерітіндіге өтеді. Қалдықтарды ерітіндіге қайта-қайта енгізу нәтижесінде оның құрамындағы мыс мөлшері тот баспайтын болаттан жасалған мысқа шөгу мүмкін болатын концентрацияға жеткізілді. Авторлар мысты талдауды LAES-Matrix лазерлік спектрометрінде зерттеулерды, сонымен қатар, өңделген кен қалдықтарының құрылымындағы өзгерістерге визуалды салыстырмалы талдауды TESCAN MIRA сканерлейтін электронды микроскопта жүргізген. Нәтижесінде тәжірибелік зертханалық қондырғыда, электрохимиялық реакциялар арқылы ерітіндіден мысты металл түрінде алу, металл мысын алуға арналған қондырғыда технологиясы зерттелді және ерітінді ортасын таңдау арқылы электрохимиялық процестер кезінде 99,99 \% тазалықпен металды алу сатына дейін зерттеулер жасалды.
\end{abstract}

Кілт сөздер: гидроимпульсті разряд, реактор, кенді су, аммоний гидрофториді, қалдық үлгілері, минералогиялық құрамы, мыс, электролиз. 
Е.С. Мустафин, Х.Б. Омаров, А.С. Борсынбаев, Д. Хавличек, А.М. Пудов, Н.В. Шуев

\title{
Получение электролитической меди из растворов выщелчивания хвостов Жезказганской обогатительной фабрики с применением гидроимпульсного разряда
}

\begin{abstract}
В статье впервые проведены исследования минералогического состава и химический полуколичественный спектральный анализ (ПСА) хвостов Жезказганской обогатительной фабрики до и после выщелачивания. Установлено, что медь присутствует в хвостах в виде минералов халькозина и борнита. После выщелачивания с применением бифторида аммония и гидроимпульсного разряда халькозин и борнит разрушаются, а медь переходит в раствор, содержащий фосфорную кислоту. В результате многократного введения хвостов в раствор содержание меди в нем доведено до концентрации, при которой возможно осаждение меди на пластинке из нержавеющей стали. Авторами проведена идентификация меди на лазерном спектрометре LAES-Matrix, визуальный сравнительный анализ изменения структуры обработанных рудных отходов на сканирующем электронном микроскопе TESCAN MIRA. Результатами стали получение металлической меди из раствора путем электрохимических реакций, отработка технологии на опытной лабораторной установке по извлечению металлической меди и доведение подбором среды раствора и электрохимических процессов до стадии получения целевого металла с чистотой $99,99 \%$.
\end{abstract}

Ключевые слова: гидроимпульсный разряд, реактор, пульпа, гидрофторид аммония, образцы хвостов, минералогический состав, электролиз, медь.

\section{References}

1 Snurnikov, A.P. (2006). Kompleksnoe ispolzovanie syria $v$ tsvetnoi metallurgii [Complex use of raw materials in non-ferrous metallurgy]. Moscow: Metallurgiia [in Russian].

2 Goryachev, A.A., Chernousenko, E.V., Potapov, S.S., Tsvetov, N.S., \& Makarov, D.V. (2021). A Study of the Feasibility of Using Ammonium Sulfate in Copper-Nickel Ore Processing, Metals, 11, 422. https://doi.org/10.3390/met11030422

3 Yutkin, L.A. (1986). Elektrogidravlicheskii effekt i ego primenenie v promyshlennosti [Electrohydraulic effect and its application in industry]. Leningrad: Mashinostroenie [in Russian].

4 Baba, A.A., Ghosh, M.K., Pradhan, S.R., Rao, D.S., Baral, A., \& Adekola, F.A.(2014). Characterization and kinetic study on ammonia leaching of complex copper ore. Transactions of Nonferrous Metals Society of China, 24, 1587-1595. https://doi.org/10.1016/S1003-6326(14)63229-5

5 Sinclair, L. \& Thompson, J. (2015). In situ leaching of copper: Challenges and future prospects. Hydrometallurgy, 157, 306324. https://doi.org/10.1016/j.hydromet.2015.08.022

6 Ochromowicz, K., Jeziorek, M., \& Wejman, K. (2014).Copper (II) extraction from ammonia leach solution. Physicochem. Probl. Miner. Process, 50, 327-335. https://doi.org/10.5277/ppmp140127

7 Medkov, M.A., Krysenko, G.F., \& Epov, D.G. (2011). Gidroftorid ammoniia — perspektivnyi reagent dlia kompleksnoi pererabotki mineralnogo syria [Ammonium hydro difluoride - a promising reagent for complex processing of mineral raw materials]. Vestnik DVO RAN - Bulletin of the Far Eastern Branch of the Russian Academy of Sciences, 5, 60-65 [in Russian].

8 Rakov, E.G. (1988). Ftoridy ammoniia [Ammonium fluorides]. Moscow: VINITI [in Russian].

9 Chukhrov, F.V. (1974). Mineraly [Minerals]. Moscow: Nauka [in Russian].

\section{Information about authors}

Mustafin Yedige Suindikovich - Full Professor, Doctor of Chemical Sciences, Director of Research Center "Applied Chemistry", Karagandy University of the name of academician E.A. Buketov, Universitetskaya street, 28, 100028, Karaganda, Kazakhstan; e-mail: edigemus@mail.ru; https://orcid.org/0000-0001-9450-9227

Omarov Khylysh Beysenovich - Full Professor, Doctor of technical sciences, Professor, Senior staff scientist of Research Center "Applied Chemistry" Karagandy University of the name of academician E.A. Buketov, Universitetskaya street, 28, 100028, Karaganda, Kazakhstan; e-mail: homarov1963@mail.ru; https://orcid.org/0000-0003-2931-652X 
David Khavlichek - Doc. RnDr. associate prof., dept. of Inorg. Chem. Faculty of science Charles University, Albertov 6, 12843 Prague 2 Czech Republic; e-mail: havlicek@natur.cuni.cz; https://orcid.org/0000-0002-8854-6213

Borsynbayev Askhat Sakenovich (corresponding author) - 3nd year PhD student, Karagandy University of the name of academician E.A. Buketov, Universitetskaya street, 28, 100028, Karaganda, Kazakhstan; e-mail: askhat.9@mail.ru; https://orcid.org/0000-0001-7709-5552

Pudov Aleksandr Mikhaylovich - Candidate of chemical sciences, Senior research of Research Center "Applied Chemistry", Karagandy University of the name of academician E.A. Buketov, Universitetskaya street, 28, 100028, Karaganda, Kazakhstan; e-mail: pudovam@list.ru; https://orcid.org/0000-0002-05666890

Shuyev Nikita Viktorovich - Master student, Karagandy University of the name of academician E.A. Buketov, Universitetskaya street, 28, 100028, Karaganda, Kazakhstan; e-mail: nick.shuev@ gmail.com 